\title{
Correlation and Path Coefficient Analysis in Rice (Oryza sativa L.) for Sodicity Tolerance
}

\author{
Hamsa Poorna Prakash ${ }^{1 *}$, O.P. Verma ${ }^{1}$, Amit Kumar Chaudhary ${ }^{1}$ \\ and Mohammad Amir ${ }^{2}$ \\ ${ }^{1}$ Department of Genetics and Plant Breeding, Seed Technology Section \\ ${ }^{2}$ Department of Genetics and Plant Breeding, Narendra Deva University of Agriculture and \\ Technology, Narendra Nagar, Kumarganj, Faizabad -224-229 (Uttar Pradesh), India \\ *Corresponding author
}

\section{A B S T R A C T}

\section{Keywords}

Rice, Correlation, Direct and indirect effect (path), Sodic

Article Info

Accepted:

04 June 2018

Available Online:

10 July 2018
The present investigation entitled "Correlation and Path coefficient analysis in Rice for sodicity tolerance" comprised of 7 lines and 3 testers recommended for sodic soil. Crosses were made in "line $\mathrm{x}$ tester mating design (Kempthorne, 1957). Thus 21 crosses ( $\mathrm{F}_{1}$ 's) were produced during 2015. The values of average degree of dominance greater than unity $(>1)$ in addition to predictability ratio $(<1)$ along with higher values of $\sigma^{2}$ SCA than $\sigma^{2}$ GCA revealed existence of over dominance for all the traits. Tester effect is higher than Line effect for all traits confirming predominant role of non-additive gene action in the inheritance of all the characters studied. Grain yield per plant showed highly significant and positive correlation with plant height, flag leaf area, panicle bearing tillers per plant, panicle length, grains per panicle, 1000 grain weight and biological yield per plant. Path analysis showed that, the high positive direct effects on grain yield per plant were exerted by biological yield per plant followed by harvest index. Hence, these traits should be emphasized during selection of rice genotypes under sodic soil.

\section{Introduction}

India is the largest rice growing country in the world, but its productivity per unit area as compared to world average is low. Asia is considered as 'Rice bowl' of the world, occupying $90 \%$ world's rice area. More than 90 per cent of the world's rice is grown and consumed in Asia, where 60 per cent of Earth's people live. Rice accounts for 35 per cent to 75 per cent of the calories consumed by more than 3 billion Asians. The rice plant can grow up to 3.3-5.9 ft. tall, depending on the variety and fertility status of soil. Blooming of spikelets starts at the apex of the panicle and proceeds downward. The blooming normally occurs between 10 AM and 2 PM. A panicle remains in bloom for 2 to 4 days but may extend up to 7- 10 days. Though it is self-pollinated extent of natural crossing varies from 0- 3\% (Poehlman, 1987). Rice is believed to have evolved around 130 million years ago (Chang, 1976). Proceedings of the National Academy of Sciences of the 
United States of America (PNAS) shows that all forms of Asian rice, both indica and japonica, spring from a single domestication that occurred 8,200-13,500 years ago in China of the wild rice Oryza rufipogon. A 2012 study published in Nature, through a map of rice genome variation, indicated that the domestication of rice occurred in the Pearl River valley region of China based on the genetic evidence. From East Asia, rice was spread to South and Southeast Asia. Rice is an excellent source of carbohydrates and also rich in magnesium, thiamine, niacin, phosphorus, vitamin $\mathrm{B}_{6}$, zinc and copper. Some varieties have iron, potassium and folic acid. Some varieties may provide $14 \mathrm{~g}$ of protein per $100 \mathrm{~g}$. The varieties of rice are typically classified as long, medium, and short-grained. The grains of long-grain rice (high in amylose) tend to remain intact after cooking; medium-grain rice (high in amylopectin) becomes stickier. Some varieties of long-grain rice are high in amylopectin, known as Thai Sticky rice. Medium-grain rice is used for sweet dishes, for risotto in Italy, and many rice dishes, such as arròsnegre, in Spain. Rice flour does not contain gluten, so is suitable for people on a gluten-free diet.

Rice is one of the important food crops that feed almost one fifth of the world's population 65 per cent of the global population and forms the cheapest source of food, energy and protein (Khush, 1997). About 90 per cent of the rice in the world is grown in Asia (nearly 640 million tons). Sub-Saharan Africa produces about 19 million tonnes and Latin America some 25 million tons. Rice is grown in about $154 \mathrm{~m}$ ha annually occupying about 11 per cent of the world's arable land. Developing countries are responsible for approximately 95 per cent of rice production and 85 per cent of rice exports. Agriculture is the mainstay of the Indian economy and contributes nearly 14.1 per cent of GDP (Economic survey, 2014-15), as about 65-70 per cent of the population is dependent on agriculture for their livelihood. Rice is the staple food for more than 60 per cent of the total population in India. The production of rice in the year 2009-10 was to the tune of 89.2 million tonnes constituting about 52 per cent of the total food grain production of India (FAOSTAT, 2014). Although country has witnessed considerable increase in rice production and productivity from $668 \mathrm{~kg} / \mathrm{ha}$ in 1951 to $2066 \mathrm{~kg} / \mathrm{ha}$ in 2011-12.In world, the production of rice is about 471.83 million tonnes (2015-16). In India area, production and productivity of rice is about 43.85 million hectares, 104.32 million tonnes and $2404 \mathrm{~kg}$ per hectare, respectively (Anonymous, 201516).

Uttar Pradesh is an important rice growing state in the country. Agriculture is the most important in the state, because, about $80 \%$ of its population resides in rural areas and $75 \%$ of the total workers are involved directly or indirectly in cultivation/farming which accounts for $27 \%$ of state's GDP. Agriculture is the main source of income for families in the state. It has 11.56 million hectare of cultivated area, constituting $70 \%$ of the total geographical area. The irrigated area is over 13.43 million hectare. Rice area with salt problem in state is estimated to be $\leq 2 \%$. Inland salinity areas are mainly concentrated in Raibareilly, Azamgarh, Sultanpur, Faizabad, Lucknow, Unnao and Pratapgarh district. The area and production of rice in this state is about 5.87 million hectare and 12.22 million tonnes, respectively and productivity of $2082 \mathrm{~kg}$ per hectare (Anonymous, 201516).

At present in the country an estimated $8.9 \mathrm{~m}$ ha of land is affected by salt of which U.P share $1.29 \mathrm{~m}$ ha. It has been estimated that increasing salinization caused by agricultural practices may lead to a loss of $30 \%$ of arable land by 2025, which may climb up to 
devasting $50 \%$ by 2050 . So it is very essential to develop elite genotypes which are suitable to saline-alkaline soil.

In this context, present investigation was under taken to evaluate twenty one experimental hybrids along with three testers, seven lines and one check in a Line $\times$ Tester design to assess heterosis and combining ability under sodic soil.

\section{Materials and Methods}

The present investigation was carried out at the Research Farm of Department of Genetics and Plant Breeding, N.D. University of Agriculture and Technology, Narendra Nagar (Kumarganj), Faizabad during kharif, 2016. Geographically this place is located in between $26.47^{0} \quad \mathrm{~N}$ latitude, $82.12^{0} \mathrm{E}$ longitudesand at an altitude of 113 meters above from mean sea level. This area falls in sub-tropical climatic zone. The climate of district Faizabad is semi-arid with hot summer and cold winter. The soil of the experimental site was partially reclaimed sodic soil. $\{\mathrm{pH}$ =9.2; $\left.\mathrm{EC}=2.21\left(\mathrm{dSm}^{-1}\right) ; \mathrm{OC}=45 \%\right\}$ The details of weather conditions recorded during evaluation period of kharif, 2016 ( $11^{\text {th }}$ June to $23^{\text {rd }}$ December).

\section{Experimental details}

The Experimental material consisted of a line $\times$ tester set of 21 hybrids $\left(F_{1} s\right)$ developed by crossing 7 lines (females) with 3 testers (males) viz., Jaya, CSR 10 and BPT 5204 of high yielding genotypes/varieties suitable for saline-alkaline condition. The Seven lines were Narendra 2026, Pusa Basmati 1, Narendra 2009, FL 478, IR-12T-193, IR-11T205 and IR-12-193. The $21 \mathrm{~F}_{1} \mathrm{~s}$ along with their parents including one check NarendraUsar 3, was evaluated in randomized block design with three replications during kharif, 2016.
The seeds were sown on $11^{\text {th }}$ June, 2016 in separate plots and 21 days ( $2^{\text {nd }}$ July, 2016) old seedlings were transplanted in sodic soil as single seedling per hill in single row plot of 3 $\mathrm{m}$ length following $20 \times 15 \mathrm{~cm}$ spacing, respectively. All the recommended cultural practices were followed to raise a good crop. The fertilizers were applied @ 120 kg nitrogen, $60 \mathrm{~kg}$ phosphorus and $60 \mathrm{~kg}$ potash per hectare through urea, DAP and murate of potash, respectively. The full dose of phosphorus and potash and half dose of the nitrogen were applied as basal and rest of nitrogen was applied in two split doses as top dressing at tillering and panicle initiation stage of the crop growth.

\section{Observations recorded}

The observations were recorded on five randomly selected competitive plants of a genotype in a plot in each replication for ten characters in the experiment. The mean values of observations recorded on five plants of each plot were used for analysis. The observations for different characters were recorded as follows:

The number of days taken from date of sowing to panicle emergence in $50 \%$ plants in a row plot was counted as days to $50 \%$ flowering. Plant height of a plant was recorded in $\mathrm{cm}$. from ground level to the tip of the main panicle excluding awns at maturity. The flag leaf area was calculated at maturity by measuring and multiplying the length and widest breadth of flag leaf and further multiplying the value by factor 0.75 .The number of panicle bearing tillers was counted in a plant at the time of maturity. The length of main panicle was measured in centimetres from the base to the tip of the panicle excluding awns. The total number of grains was counted in each panicle of a plant after harvesting the crop. The weight of 1000-filled grains sampled from five randomly selected 
plants taken in a plot was weighed in grams. The total biomass excluding roots of a plant was sun-dried and dry matter was weighed in grams. The ratio of grain yield per plant $(\mathrm{g})$ to biological yield per plant (g) of a plant was considered as harvest-index and expressed in percentage. The value was calculated as:

Harvest index $(\%)=\frac{\text { Grain yield per plant }(\mathrm{g})}{\text { Biological yield per plant }(\mathrm{g})} \times 100$

The grains of each selected plant were hand threshed and sun-dried. The weight of the grains obtained from a plant was taken on an electronic balance in grams. The experimental data collected on all the ten characters in respect of experiment of the present study were compiled by taking the mean values over five randomly selected plants in each plot in each replication. It was then subjected to various statistical and genetical analyses.

1. Computation of correlation coefficient (Searle, 1961)

2. Path coefficient analysis (Dewey and $\mathrm{Lu}, 1959)$

\section{Computation of correlation coefficient}

The simple correlation coefficient between different characters was estimated according to Searle (1961) as follows: Correlation coefficient ( $\mathrm{r}$ ) between characters $\mathrm{x}$ and $\mathrm{y}$, $r_{x y}=\frac{\text { Cov.xy }}{\sqrt{(\text { Var.x X var.y })}}$

Where,

$r_{x y}=$ Correlation coefficient between characters $\mathrm{x}$ and $\mathrm{y}$.

Cov.xy $=$ Covariance between characters $\mathrm{x}$ and $\mathrm{y}$.

Var. $\mathrm{x}=$ Variance for $\mathrm{x}$ character.

Var.y $=$ Variance for $\mathrm{y}$ character.

The significance of correlation coefficient was tested by comparing at an appropriate level of significance, the significant values of (r) at (n2) degrees of freedom, where ' $n$ ' is number of genotypes.

\section{Path coefficient analysis}

Path coefficient analysis was carried out according to Dewey and $\mathrm{Lu}$ (1959). Grain yield per plant was assumed to be dependent variable (effect) which was influenced by the nine characters, the independent variables (causes), directly as well as indirectly through other characters. The variation in grain yield per plant unexplained by the nine causes was presumed to be contributed by a residual factor (x) which is uncorrelated with other factors. Path-coefficients were estimated by solving the following simultaneous equations indicating the basic relationship between correlation and path coefficient. The equations used are as follows:

$$
\begin{aligned}
& r_{i y}=P_{i y}+\sum_{j=1}^{9} r_{i j} P_{j y} \text { for } i=1,2, \ldots \ldots \ldots 9 \\
& r_{i y}=\sum_{j=1}^{9} r_{i j} P_{j y} \text { for } r_{i i}=1
\end{aligned}
$$

The above equations can be written in the form of matrix:

$[\mathrm{A}]_{9 \times 1}=[\mathrm{B}]_{9 \times 1}[\mathrm{C}]_{9 \times 1}$

Where,

A is column vector of correlations $r_{i y}$,

$B$ is the correlation matrix of $r_{i j}$, and

$\mathrm{C}$ is the column vector of direct effects, $\mathrm{P}_{\mathrm{iy}}$

Residual factor was calculated as follows:

$\mathrm{P}_{\mathrm{xy}}=\sqrt{1-\mathrm{R}^{2}}$

Where,

$R^{2}=\sum_{j} P_{i y} r_{i y}$ 
The $r_{i j}$ s i.e. $r_{1.2}$ to $r_{9.10}$ denote correlations between all possible combinations of independent characters and $\mathrm{P}_{1 \mathrm{y}}$ to $\mathrm{P}_{9 \mathrm{y}}$ denote direct effects of various characters on character $\mathrm{y}$.

$\mathrm{r}_{\mathrm{iy}}=$ Correlation coefficient between $\mathrm{i}^{\text {th }}$ and $\mathrm{y}$ character.

$P_{i y}=$ Direct effect of $i^{\text {th }}$ character on $y$.

\section{Results and Discussion}

The demand for rice continues to rise because of population growth and improvement in living standards. In last two decades, a number of high yielding varieties were developed and have achieved popularity in the farming community because of being high yielding; however, a yield plateau has been experienced for the last few years. Therefore, to device a breeding methodology to unfold the genetic information for various metric traits is prerequisite. Hybrid rice technology offer an opportunity for vertical growth through increase in productivity due to yield advantage of 15-20 per cent over the conventional high yielding varieties (Virmani, 1996). Success of hybrid rice technology on commercial basis in China during mid-eighties revealed that utilization of the phenomenon of hybrid vigour is one of the feasible options to get quantum jump in rice potential yield by 20-30 per cent over the best available inbred rice (Yuan and Virmani, 1988). China is currently having about 55 per cent of its total hectare under hybrids producing 18 million tonnes of extra paddy per annum (Virmani, 1992). Since 1979, IRRI and several countries in Asia including India have been exploring the potential and problems of commercial exploitation of heterosis. The knowledge of nature and magnitude of gene actions involved in different quantitative traits is thus necessary for reorientation of breeding methodologies on systematic lines so that a breeder can come to the logical conclusion. To break the yield barriers, in the non-existence of scope through horizontal growth, the development of hybrid rice is being realized as a felt need. Therefore, the present investigation entitled "Correlation and Path coefficient analysis in Rice for sodicity tolerance" was under taken with the objectives to estimate correlation coefficient and path coefficient analysis among yield and its contributing components,

\section{Correlation coefficient}

The correlation coefficient is the measure of degree of symmetrical association between two variables or characters which helps us in understanding the nature and magnitude of association among yield and yield components. Grain yield, is the complex character. The genetic architecture of grain yield in rice as well as other crops is based on the balance or overall net effect produced by various yield components directly or indirectly by interacting with one another. Therefore, selection for yield per se alone would not serve the purpose until and unless accompanied by the selection for various component characters responsible for conditioning it. Thus, identification of important components and information about their association with yield with other traits are very useful for developing efficient breeding strategy for evolving high yielding varieties.

In the present investigation, phenotypic and genotypic correlation coefficients were computed among ten characters (Table 1). Grain yield per plant showed highly significant and positive correlation with flag leaf area, panicle bearing tillers per plant, panicle length, grains per panicle, 1000 grain weight, biological yield per plant and harvest index. Therefore, these characters emerged as most important associates of grain yield in rice. The strong positive association of grain 
yield with the characters mentioned above has also being reported in rice by earlier workers (Verma and Srivastava, 2004; Qamar et al., 2005; Ramkrishnan et al., 2006; Nandan et al., 2010; Akhtar et al., 2011; Kumar et al., 2011; Bhadru et al., 2011; Rangare et al., 2012; Krishnamurthy and Kumar, 2012). In general, genotypic correlations were higher than phenotypic ones in magnitude for all the characters. The characters which showed negative correlation at genotypic level also showed negative correlation at phenotypic level. Days to $50 \%$ flowering showed negative non-significant correlation at both levels with plant height (-0.0030), flag leaf area (-0.0475), panicle bearing tillers per plant (-0.1983), panicle length (-0.0897). 1000-grain weight ($0.1941)$, biological yield per plant (-0.1296), harvest-index (-0.1605) and grain yield per plant (-0.1509) and negative and significant correlation with Grains per panicle $(-0.2269)$ at phenotypic level.

Plant height showed highly significant and positive correlation with panicle length (0.3506) at phenotypic level, whereas positively non-significant association was found for flag leaf are (0.1017), 1000-grain weight $(0.1583)$ and harvest index (0.0245).

Negative non- significant association was showed with panicle bearing tillers per plant (0.1118), and biological yield per plant ($0.0605)$ at both levels. Whereas negative and significant association was found with grains per panicle $(-0.2027)$ at phenotypic level.Flag leaf area showed highly significant and positive correlation with panicle length (0.3690), panicle bearing tillers per plant (0.5728), grains per panicle (0.5498), 1000grain weight $(0.5248)$, biological yield per plant (0.5991), Harvest index (0.5370) and grain yield per plant (0.6521) at phenotypic level. Panicle bearing tillers per plant had highly significant and positive correlation with panicle length (0.3450), grains per panicle
(0.7138), 1000-grain weight (0.5126), biological yield per plant (0.7171), harvest index (0.4563) and grain yield per plant (0.7251). Panicle length had highly significant and positive correlation with 1000-grain weight (0.3620) biological yield per plant (0.4279) and grain yield per plant (0.4227) but grains per plant $(0.2513)$ and harvest index (0.2155) were found positive significant correlation. Grains per panicle showed highly significant positive correlation with 1000grain weight (0.5164), biological yield per plant (0.8574), harvest index (0.5326) and grain yield per plant (0.8592) at both level.1000-grain weight exhibited highly significant and positive correlation with biological yield per plant (0.5236), harvest index (0.3636) and grain yield per plant (0.5419) at both level.

Biological yield per plant had highly significant and positive association with harvest index (0.5073) and grain yield per plant (0.9740). Harvest index per plant had highly significant and positive association with grain yield per plant (0.6828). According to present study 24 significant estimates obtained between different character pairs, 3 correlation coefficients were positive in nature, while, 9 estimates were negative.

This represents highly favourable situation for obtaining high response to selection in improving yield and yield components in rice. Thus, selection practiced for improving these traits individually or simultaneously would bring improvement in other due to correlated response. The estimates of correlation coefficients obtained in present study are in agreement with previous reports in rice (Verma and Srivastava, 2004; Kishore et al., 2007; Rangare et al., 2012; Krishnamurthy and Kumar, 2012), Mohamed et al., (2012), Pankaj et al., (2013) and Sudharani et al., (2013). 
Table.1Estimation of phenotypic $(\mathrm{P})$ and genotypic $(\mathrm{G})$ correlation coefficients for ten characters in rice

\begin{tabular}{|c|c|c|c|c|c|c|c|c|c|c|c|c|}
\hline S.N. & Character & & $\begin{array}{l}\text { Days to } \\
50 \% \\
\text { flowering }\end{array}$ & $\begin{array}{l}\text { Plant } \\
\text { height }(\mathrm{cm})\end{array}$ & $\begin{array}{l}\text { Flag leaf } \\
\text { area } \\
\left(\mathrm{cm}^{2}\right)\end{array}$ & $\begin{array}{l}\text { Panicle } \\
\text { bearing } \\
\text { tillers per } \\
\text { plant }\end{array}$ & $\begin{array}{l}\text { Panicle } \\
\text { length }(\mathrm{cm})\end{array}$ & $\begin{array}{l}\text { Grains per } \\
\text { panicle }\end{array}$ & $\begin{array}{l}\text { 1000- grain } \\
\text { weight (g) }\end{array}$ & $\begin{array}{l}\text { Biological } \\
\text { yield per } \\
\text { plant (g) }\end{array}$ & $\begin{array}{l}\text { Harvest- } \\
\text { index }(\%)\end{array}$ & $\begin{array}{l}\text { Grain yield } \\
\text { per pant }(\mathrm{g})\end{array}$ \\
\hline \multirow[t]{2}{*}{1} & \multirow[t]{2}{*}{ Days to $50 \%$ flowering } & $\mathrm{P}$ & 1.0000 & -0.0030 & -0.0475 & -0.1983 & -0.0897 & $-0.2269 *$ & -0.1941 & -0.1296 & -0.1605 & -0.1509 \\
\hline & & $\mathrm{G}$ & 1.0000 & -0.0024 & -0.0461 & -0.2890 & -0.0944 & -0.2292 & -0.2131 & -0.1273 & -0.2006 & -0.1470 \\
\hline \multirow[t]{2}{*}{2} & \multirow[t]{2}{*}{ Plant height $(\mathrm{cm})$} & $\mathbf{P}$ & & 1.0000 & 0.1017 & -0.1118 & $0.3506^{* *}$ & $-0.2027 *$ & 0.1583 & -0.0605 & 0.0245 & -0.0365 \\
\hline & & G & & 1.0000 & 0.1102 & -0.1324 & 0.3808 & -0.2161 & 0.1617 & -0.0658 & 0.0062 & -0.0444 \\
\hline \multirow[t]{2}{*}{3} & \multirow[t]{2}{*}{ Flag leaf area $\left(\mathrm{cm}^{2}\right)$} & $\mathrm{P}$ & & & 1.0000 & $0.5728 * *$ & $0.3690 * *$ & $0.5498 * *$ & $0.5248 * *$ & $0.5991 * *$ & $0.5370 * *$ & $0.6521 * *$ \\
\hline & & G & & & 1.0000 & 0.8497 & 0.4043 & 0.6192 & 0.6142 & 0.6708 & 0.7542 & 0.7283 \\
\hline \multirow[t]{2}{*}{4} & \multirow{2}{*}{$\begin{array}{l}\text { Panicle bearing tillers } \\
\text { per plant }\end{array}$} & $\mathrm{P}$ & & & & 1.0000 & $0.3450 * *$ & $0.7138 * *$ & $0.5126^{* *}$ & $0.7171 * *$ & $0.4563 * *$ & $0.7251 * *$ \\
\hline & & $\mathrm{G}$ & & & & 1.0000 & 0.4525 & 0.9757 & 0.6512 & 0.9834 & 0.8602 & 1.0083 \\
\hline \multirow[t]{2}{*}{5} & \multirow[t]{2}{*}{ Panicle length $(\mathrm{cm})$} & $\mathrm{P}$ & & & & & 1.0000 & $0.2513^{*}$ & $0.3620 * *$ & $0.4279 * *$ & $0.2155^{*}$ & $0.4227 * *$ \\
\hline & & G & & & & & 1.0000 & 0.2722 & 0.4234 & 0.4776 & 0.3510 & 0.4771 \\
\hline \multirow[t]{2}{*}{6} & \multirow[t]{2}{*}{ Grains per panicle } & $\mathrm{P}$ & & & & & & 1.0000 & $0.5164 * *$ & $0.8574 * *$ & $0.5326^{* *}$ & $0.8592 * *$ \\
\hline & & $\mathrm{G}$ & & & & & & 1.0000 & 0.5734 & 0.9136 & 0.7416 & 0.9200 \\
\hline \multirow[t]{2}{*}{7} & \multirow[t]{2}{*}{ 1000- grain weight $(\mathrm{g})$} & $\mathrm{P}$ & & & & & & & 1.0000 & $0.5236^{* *}$ & $0.3636^{* *}$ & $0.5419 * *$ \\
\hline & & G & & & & & & & 1.0000 & 0.5707 & 0.4494 & 0.5807 \\
\hline \multirow[t]{2}{*}{8} & \multirow{2}{*}{$\begin{array}{l}\text { Biological yield per } \\
\text { plant }(\mathrm{g})\end{array}$} & $\mathrm{P}$ & & & & & & & & 1.0000 & $0.5073 * *$ & $0.9740 * *$ \\
\hline & & $\mathrm{G}$ & & & & & & & & 1.0000 & 0.7046 & 0.9863 \\
\hline \multirow[t]{2}{*}{9} & \multirow[t]{2}{*}{ Harvest-index (\%) } & $\mathrm{P}$ & & & & & & & & & 1.0000 & $0.6828 * *$ \\
\hline & & $\mathrm{G}$ & & & & & & & & & 1.0000 & 0.8094 \\
\hline
\end{tabular}

$*, * *$ Significant at $5 \%$ and $1 \%$ probability levels, respectively 
Table.2 Direct and indirect effects of 10 characters on grain yield per plant at phenotypic (P) and genotypic (G) levels in rice

\begin{tabular}{|c|c|c|c|c|c|c|c|c|c|c|c|c|}
\hline No & Character & & $\begin{array}{l}\text { Days to } 50 \% \\
\text { flowering }\end{array}$ & $\begin{array}{l}\text { Plant } \\
\text { height } \\
(\mathrm{cm})\end{array}$ & $\begin{array}{l}\text { Flag leaf } \\
\text { area } \\
\left(\mathrm{cm}^{2}\right)\end{array}$ & $\begin{array}{l}\text { Panicle } \\
\text { bearing } \\
\text { tillers per } \\
\text { plant }\end{array}$ & $\begin{array}{l}\text { Panicle } \\
\text { length } \\
(\mathrm{cm})\end{array}$ & $\begin{array}{l}\text { Grains } \\
\text { per } \\
\text { panicle }\end{array}$ & $\begin{array}{l}\text { 1000- } \\
\text { grain } \\
\text { weight }(g)\end{array}$ & $\begin{array}{l}\text { Biological } \\
\text { yield per } \\
\text { plant }(\mathrm{g})\end{array}$ & $\begin{array}{l}\text { Harvest- } \\
\text { index }(\%)\end{array}$ & $\begin{array}{l}\text { Correlation } \\
\text { with Grain } \\
\text { yield per } \\
\text { pant (g) }\end{array}$ \\
\hline \multirow[t]{2}{*}{1} & \multirow[t]{2}{*}{ Days to $50 \%$ flowering } & $\mathbf{P}$ & -0.0006 & 0.0000 & 0.0000 & 0.0001 & 0.0001 & 0.0001 & 0.0001 & 0.0001 & 0.0001 & -0.1509 \\
\hline & & $\mathbf{G}$ & 0.0008 & 0.0000 & 0.0000 & -0.0002 & -0.0001 & -0.0002 & -0.0002 & -0.0001 & -0.0002 & -0.1470 \\
\hline \multirow[t]{2}{*}{2} & \multirow[t]{2}{*}{ Plant height $(\mathrm{cm})$} & $\mathrm{P}$ & 0.0000 & 0.0053 & 0.0005 & -0.0006 & 0.0019 & -0.0011 & 0.0008 & -0.0003 & 0.0001 & -0.0365 \\
\hline & & G & 0.0000 & 0.0024 & 0.0003 & -0.0003 & 0.0009 & -0.0005 & 0.0004 & 0.0002 & 0.0000 & -0.0444 \\
\hline \multirow[t]{2}{*}{3} & \multirow[t]{2}{*}{ Flag leaf area $\left(\mathrm{cm}^{2}\right)$} & $\mathrm{P}$ & -0.0006 & 0.0013 & 0.0129 & 0.0074 & 0.0048 & 0.0071 & 0.0068 & 0.0077 & 0.0069 & $0.6521 * *$ \\
\hline & & G & 0.0000 & 0.0001 & 0.0008 & 0.0007 & 0.0003 & 0.0005 & 0.0005 & 0.0005 & 0.0006 & 0.7283 \\
\hline \multirow[t]{2}{*}{4} & \multirow[b]{2}{*}{$\begin{array}{l}\text { Panicle bearing tillers } \\
\text { per plant }\end{array}$} & $\mathrm{P}$ & -0.0007 & -0.0004 & 0.0019 & 0.0033 & 0.0012 & 0.0024 & 0.0017 & 0.0024 & 0.0015 & $0.7251 * *$ \\
\hline & & G & 0.0054 & 0.0025 & -0.0159 & -0.0187 & -0.0085 & -0.0183 & -0.0122 & -0.0184 & -0.0161 & 1.0083 \\
\hline \multirow[t]{2}{*}{5} & \multirow[t]{2}{*}{ Panicle length $(\mathrm{cm})$} & $\mathrm{P}$ & -0.0002 & 0.0009 & 0.0009 & 0.0009 & 0.0025 & 0.0006 & 0.0009 & 0.0011 & 0.0005 & $0.4227 *$ \\
\hline & & G & 0.0006 & -0.0025 & -0.0027 & -0.0030 & -0.0066 & -0.0018 & -0.0028 & -0.0032 & -0.0023 & 0.4771 \\
\hline \multirow[t]{2}{*}{6} & \multirow[t]{2}{*}{ Grains per panicle } & $\mathrm{P}$ & 0.0002 & 0.0002 & -0.0005 & -0.0007 & -0.0002 & -0.0010 & -0.0005 & -0.0008 & -0.0005 & $0.8592 * *$ \\
\hline & & $\mathrm{G}$ & 0.0059 & 0.0055 & -0.0158 & -0.0249 & -0.0070 & -0.0256 & -0.0147 & -0.0233 & -0.0190 & 0.9200 \\
\hline \multirow[t]{2}{*}{7} & \multirow[t]{2}{*}{ 1000- grain weight (g) } & $\mathrm{P}$ & -0.0008 & 0.0006 & 0.0021 & 0.0021 & 0.0015 & 0.0021 & 0.0041 & 0.0021 & 0.0015 & $0.5419 * *$ \\
\hline & & G & -0.0032 & 0.0024 & 0.0092 & 0.0098 & 0.0063 & 0.0086 & 0.0150 & 0.0085 & 0.0067 & 0.5807 \\
\hline \multirow[t]{2}{*}{8} & \multirow{2}{*}{$\begin{array}{l}\text { Biological yield per } \\
\text { plant }(\mathrm{g})\end{array}$} & $\mathrm{P}$ & -0.1083 & -0.0506 & 0.5006 & 0.5991 & 0.3575 & 0.7164 & 0.4375 & 0.8355 & 0.4239 & $0.9740 * *$ \\
\hline & & G & -0.1089 & -0.0563 & 0.5740 & 0.8415 & 0.4087 & 0.7818 & 0.4883 & 0.8557 & 0.6029 & 0.9863 \\
\hline \multirow[t]{2}{*}{9} & \multirow[t]{2}{*}{ Harvest-index $(\%)$} & $\mathrm{P}$ & -0.0399 & 0.0061 & 0.1336 & 0.1135 & 0.0536 & 0.1325 & 0.0905 & 0.1262 & 0.2488 & $0.6828 * *$ \\
\hline & & G & -0.0475 & 0.0015 & 0.1785 & 0.2036 & 0.0831 & 0.1755 & 0.1064 & 0.1668 & 0.2367 & 0.8094 \\
\hline
\end{tabular}

*, **: Significant at $5 \%$ and $1 \%$ probability levels, respectively.

Residual effectphenotypic path and genotypic path 0.0567 and 0.0315 respectively.

Bold diagonal values indicates the direct effect. 


\section{Path coefficient analysis}

The concept of path coefficient was developed by Wright (1921) and technique was first used for plant selection by Dewey and $\mathrm{Lu}$ (1959). Path analysis has emerged as a powerful and widely used technique for understanding the direct and indirect contributions of different characters to economic yield in crop plants so that the relative importance of various yield contributing characters can be assessed. In the present study, the path coefficient analysis was carried out using correlation coefficients between ten characters. The high positive direct effects on grain yield per plant were exerted by biological yield per plant followed by harvest index. The direct and indirect effects of ten characters on grain yield per plant estimated by path coefficient analysis using phenotypic as well as genotypic correlation coefficients are given in (Table 2). The highest positive direct effect on grain yield per plant was exerted by biological yield per plant (0.8355) followed by harvest index (0.2488) while the highest negative direct effect on grain yield per plant was exerted by grains per panicle (-0.0010) followed by days to $50 \%$ flowering $(-0.0006)$. These characters have also been identified as major direct contributors towards grain yield by Verma and Srivastava, 2004; Nandan et al., 2010; Akhtar et al., 2011 Kumar et al., 2011; Bhadru et al., 2011; Rangare et al., 2012; Krishnamurthy and Kumar, 2012. The direct effects of remaining five characters were too low to be considered important. Grains per panicle ( 0.7164$)$ followed by panicle bearing tillers per plant (0.5991), flag leaf area $(0.5006), 1000$-grain weight $(0.4375)$ and harvest index (0.4239) and panicle length (0.3575) exhibited high order of positive indirect effect on grain yield per plant via biological yield per plant, while negative indirect effect on grain yield per plant was exerted by days to biological yield per plant
$(-0.1083)$ and (-0.0506), followed harvest index (-.0.0399) and grains per panicle (0.0008 ). The remaining estimates of indirect effects in this analysis were too low to be considered of any consequence. The estimates of residual factors (0.0567) were negligible. The remaining estimates of indirect effects in this analysis were too low to be considered of any consequence. Patil and Sarawgi (2006), Zahid et al., (2006), Kishore et al., (2007) and Babar et al., (2009) have also identified biological yield and harvest index as important direct and indirect yield contributing characters. The indirect effects of remaining characters were too low to be considered important.

In addition to emerging as most important direct yield contributors owing to their very high positive direct effects on grain yield per plant; biological yield per plant and harvest index having considerable positive indirect effects via different characters, also appeared as most important indirect yield components. Verma and Srivastava, 2004; Kishore et al., (2007) and Babar et al., (2009), Nandan et al., (2010), Kumar et al., (2011), Rangare et al., (2012), have also identified biological yield and harvest index as important direct and indirect yield contributing characters.

The indirect effects of remaining characters were too low to be considered important. Results revealed that, path analysis identified biological yield per plant followed by harvest index as most important direct as well as indirect yield contributing traits which merit due consideration at time of devising selection strategy aimed at developing high yielding varieties in rice.

Hence concluded with the present investigation entitled "Correlation and Path Coefficient Analysis in Rice (Oryza sativa L.) for Sodicity tolerance" was undertaken to estimate correlation coefficient and path 
coefficient analysis among yield and its contributing components.

The salient findings of present study are summarized as:

1. Grain yield per plant showed positive and significant correlation with panicle bearing tillers per plant, grains per panicle and 1000grain weight to emerge as most important associates of grain yield in rice. This suggested that selection would be quite efficient in improving yield and yield components.

2. Path analysis revealed that the highest positive direct effect on grain yield per plant was exerted by biological yield per plant followed by harvest-index, while grains per panicle followed by panicle bearing tillers per plant exerted highest negative direct effect on grain yield per plant. It refers that more emphasis should be given to select these traits to increase the production and productivity of rice under sodic soil.

3. Panicle bearing tillers per plant, grains per panicle and 1000-grain weight exhibited high and positive indirect effect on grain yield via biological yield per plant while, days to $50 \%$ flowering and plant height exhibited high and negative indirect effect on grain yield via biological yield per plant which can be taken into consideration to devise suitable strategy.

\section{Acknowledgement}

The authors are thankful to Dr. P.K. Singh, Professor and Head of the Department, Genetics and Plant Breeding, Narendra Deva University of Agriculture and Technology, Kumarganj, Faizabad for providing research field and all essentials. In addition, the authors thank Nayana P. Department of Biotechnology, Kuvempu University, shivmogga for suggestion and Prakash V. K. and Annapurna R. for financial support.

\section{References}

Akhtar, N., Nazir, M.F., Rabnawaz, A., Mahmood, T., Safdar, M. E., Asif, M. and Rehman, A. (2011).Estimation of heritability, correlation and path coefficient analysis in fine grain rice (Oryza sativa L.). The J. Animal Plant Sci., 21 (4):660-664.

Babar, M., Khan, A. A., Arif, A., Zafar, Y. and Arif, M. (2009).Path analysis of some leaf and panicle traits affecting grain yield in double haploid lines of rice (Oryza sativa L.). J. Agric. Res., 45 (4):245-252.

Bhadru, D., Reddy, D. L. and Ramesha, M. S. (2011). Correlation and path coefficient analysis of yield and yield contributing traits in rice hybrids and their parental lines. Electronic J. of Plant Breed.,2 (1):112-116.

Dewey, D. R. and Lu, K.H. (1959). Correlation and path coefficient analysis of crested wheat grass seed production. Agron. J.,51:515-518.

Kishore, N. S., Ansari, N. A., Babu, V. R., Rani, N. S., Rao, L. V. and Subba, R. (2007). Correlation and path analysis in aromatic and non-aromatic rice genotypes. Agril. Sci. Digest, 27: Issue 2.

Krishnamurthy, H. T. and Kumar, H. D. M. (2012). Correlation and path coefficient studies of some physiological traits among indigenous aromatic rice (Oryza sativa L.) cultivars. Agril. Bio. Res., 28 (2):120127.

Kumar, Y., Singh, B.N., Verma, O.P., Tripathi, S. and Dwivedi, D.K. (2011). Correlation and path coefficient analysis in scented rice (Oryza sativa L.) under sodicity. Environment and Ecology, 29 (3B):1550-1556.

Mohamed, K. A., Idris, A. E., Mohammed, H. I. and Adam, K. A. O. (2012).Ranking rice (Oryza sativa L.) genotypes using 
multi-criteria decision making, correlation and path coefficient analysis. Biotech. J., 2 (4):211-228.

Nandan, R., Sweta and Singh, S.K. (2010). Character association and path analysis in rice (Oryza sativaL.) genotypes. World J. Agril Sci., 6 (2):201-206.

Pankaj Bhatia, Jain, R. K. and Chowdhury, V. K. (2013).Genetic variability, correlation and path coefficient analysis for grain yield and its components in rice (Oryza sativa $\mathrm{L}$.). Annuals of Bio., 29 (3):282-287.

Patil, P.V. and Sarawgi, A.K. (2006).Studies on genetic variability, correlation and path analysis in traditional aromatic rice accessions.Ann. Plant Physiology, 19 (1):92-95.

Poehlman, J.M. 1987. Breeding Field Crops.III Edition. AVI Publ. Co. Westport, Connecticut. Pp. 340-377.

Qamar, Z. U., Cheema, A. A., Ashraf, M., Rashid, M. and Tahir, G.R. (2005). Association analysis of some yield influencing traits in aromatic and nonaromatic rice. Pak. J. Bot.,37 (3):613627.

Ramakrishnan, S. H., Kumar, A. C. R., Sarvanan, S. and Malini, N. (2006). Association analysis of some yield traits in Rice (Oryza sativa L.).J. Applied Sci. Res., 2 (7):402-404.

Rangare, N. R., Krupakar, A., Ravichandra, K., Shukla, A. K. and Mishra, A. K.
(2012).Estimation of characters association and direct and indirect effects of yield contributing traits on grain yield in exotic and Indian rice (Oryza sativaL.) germplasm. International J. of Agric. Science, 2 (1):54-61.

Sudharani, M., Reddy, P. R., Reddy, G. H. and Raju, C. S. (2013).Correlation and path coefficient analysis for yield and physiological attributes in rice (Oryza sativa L.) hybrids under saline soil conditions. J. Res. ANGRAU, 41 (1): $105-108$.

Verma O. P. and Srivastava H. K. (2004).Productivity Association of Quantitative traits in Diverse Ecotypes of Rice (Oryza sativa L.). J. Sustainable Agric. 25 (2):75-91.

Virmani, S.S. (1996). Hybrid rice.Advan.inAgron., 57:328-462.

Wright, S. (1921). Correlation and causation.J. Agric. Res., 203:557-585.

Yuan, L. P. and Virmani, S. S. (1988).Status of hybrid rice research and development. In: Hybrid Rice, International Rice Research Institute, Manila, Philippines, pp. 7-24.

Zahid, M. A., Akhter, M., Sabar, M., Zaheen, M. and Tahir, A. (2006). Correlation and path analysis studies of yield and economic traits in Basmati rice (Oryza sativa L.), Asian Journal of Plant Sciences, 5(4): 643-645.

\section{How to cite this article:}

Hamsa Poorna Prakash, O.P. Verma, Amit Kumar Chaudhary and Mohammad Amir. 2018. Correlation and Path Coefficient Analysis in Rice (Oryza sativa L.) for Sodicity Tolerance. Int.J.Curr.Microbiol.App.Sci. 7(07): 177-187. doi: https://doi.org/10.20546/ijcmas.2018.707.022 